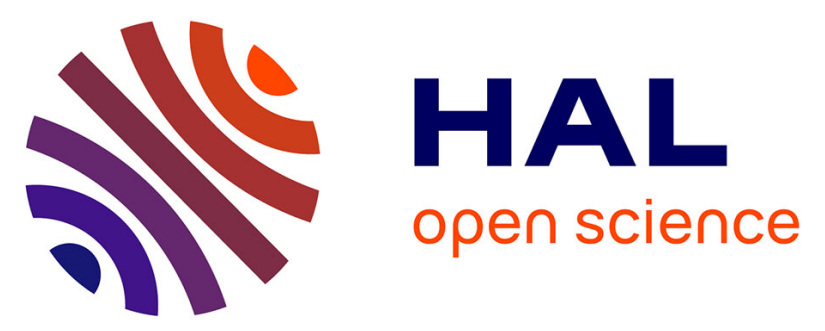

\title{
Meeting report: Vienna 2008 Workshop of the German-Austrian Working Group for Studying Prognostic Factors in Myelodysplastic Syndromes
}

Peter Valent, Wolf-Karsten Hofmann, Guntram Büsche, Karl Sotlar, Hans-Peter Horny, Detlef Haase, Torsten Haferlach, Wolfgang Kern, Peter

Bettelheim, Christian Baumgartner, et al.

\section{To cite this version:}

Peter Valent, Wolf-Karsten Hofmann, Guntram Büsche, Karl Sotlar, Hans-Peter Horny, et al.. Meeting report: Vienna 2008 Workshop of the German-Austrian Working Group for Studying Prognostic Factors in Myelodysplastic Syndromes. Annals of Hematology, 2009, 88 (7), pp.607-611. 10.1007/s00277-008-0673-7 . hal-00535018

\section{HAL Id: hal-00535018 https://hal.science/hal-00535018}

Submitted on 11 Nov 2010

HAL is a multi-disciplinary open access archive for the deposit and dissemination of scientific research documents, whether they are published or not. The documents may come from teaching and research institutions in France or abroad, or from public or private research centers.
L'archive ouverte pluridisciplinaire HAL, est destinée au dépôt et à la diffusion de documents scientifiques de niveau recherche, publiés ou non, émanant des établissements d'enseignement et de recherche français ou étrangers, des laboratoires publics ou privés. 


\title{
Meeting report: Vienna 2008 Workshop of the German-Austrian Working Group for Studying Prognostic Factors in Myelodysplastic Syndromes
}

\author{
Peter Valent • Wolf-Karsten Hofmann • \\ Guntram Büsche • Karl Sotlar • Hans-Peter Horny • \\ Detlef Haase • Torsten Haferlach • Wolfgang Kern • \\ Peter Bettelheim • Christian Baumgartner • \\ Wolfgang R. Sperr • Thomas Nösslinger • \\ Friedrich Wimazal • Aristoteles A. Giagounidis • \\ Michael Lübbert • Otto Krieger • Hans-Jochem Kolb • \\ Reinhard Stauder • Michael Pfeilstöcker • \\ Norbert Gattermann • Christa Fonatsch • Carlo Aul • \\ Ulrich Germing
}

Received: 8 December 2008 / Accepted: 14 December 2008/Published online: 16 January 2009

(C) Springer-Verlag 2009

\begin{abstract}
Criteria, scoring systems, and treatment algorithms for myelodysplastic syndromes (MDS) have been updated repeatedly in recent years. This apparently results from increased awareness and early recognition of the disease, an increasing number of new diagnostic and prognostic markers and tools, and new therapeutic options that may change the course and thus prognosis in MDS. To
\end{abstract}

P. Valent $(\bowtie) \cdot$ C. Baumgartner $\cdot$ W. R. Sperr $\cdot$ F. Wimazal

Department of Internal Medicine I, Division of Hematology

\& Hemostaseology, Medical University of Vienna,

Waehringer Guertel 18-20,

1090 Vienna, Austria

e-mail: peter.valent@meduniwien.ac.at

W.-K. Hofmann

Department of Hematology, Oncology and Transfusion Medicine, Charité University Hospital,

Campus Benjamin Franklin,

Berlin, Germany

G. Büsche

Institute of Pathology, Medizinische Hochschule Hannover,

Hannover, Germany

\section{K. Sotlar}

Institute of Pathology, Ludwig-Maximilians-Universität München, München, Germany

\section{H.-P. Horny}

Klinikum Ansbach, Institute of Pathology,

Ansbach, Germany address these challenges and to create useful new diagnostic and prognostic parameters and scores, the GermanAustrian Working Group for Studying Prognostic Factors in MDS was established in 2003 and later was extended to centers in Switzerland (D-A-CH group). In addition, the group cooperates with the European LeukemiaNet, the MDS Foundation, and other national and international

D. Haase

Department of Hematology and Oncology,

Georg-August-University,

Göttingen, Germany

T. Haferlach • W. Kern

MLL Munich Leukemia Laboratory,

Munich, Germany

P. Bettelheim

Institute for Laboratory Medicine, Otto Wagner Hospital Vienna,

Vienna, Austria

T. Nösslinger $\cdot$ M. Pfeilstöcker

Ludwig-Boltzmann Institute for Leukemia Research

and Hematology, Hanusch Hospital,

Vienna, Austria

A. A. Giagounidis $\cdot$ C. Aul

Medizinische Klinik II, St. Johannes Hospital Duisburg,

Duisburg, Germany 
working groups in order to improve diagnosis and prognostication. The current article represents a meeting report from the latest workshop organized by the group in Vienna in October 2008.

Keywords Myelodysplastic syndromes $\cdot$ Criteria . Prognostication $\cdot$ Standardization $\cdot$ MDS registry

\section{Introduction}

Myelodysplastic syndromes (MDS) usually develop in an advanced phase of life, often as slowly progressing anemia in comorbid patients [1]. The awareness for MDS has increased, and better diagnostic tests are available. On the other hand, many new questions concerning the diagnosis, classification, and prognostication in MDS have emerged in recent years [1]. Based on these developments, centers specialized in the diagnosis and management of MDS have started to discuss criteria, classification issues, and prognostic factors. Our working group has launched a series of annual meetings as well as several international meetings in order to intensify collaboration within the group and also with other working groups. A key aim is to initiate and conduct scientific projects and clinical trials in patients with MDS in order to identify new risk factors and to improve prognostication and therapy. In addition, we have established a central data registry. Table 1 shows a summary of major aims of the German-Austrian MDS Working Group. In the year 2006, a working conference in Vienna was

\author{
M. Lübbert \\ Division of Hematology/Oncology, Department of Medicine, \\ University of Freiburg, \\ Freiburg, Germany \\ O. Krieger \\ First Department of Internal Medicine, Elisabethinen Hospital, \\ Linz, Austria \\ H.-J. Kolb \\ Department of Medicine III, University of Munich, \\ GSF-National Research Centre for Environment and Health, \\ Munich, Germany \\ R. Stauder \\ Division of Hematology and Oncology, \\ Innsbruck Medical University, \\ Innsbruck, Austria \\ N. Gattermann $\cdot$ U. Germing \\ Department of Hematology Oncology and Clinical Immunology, \\ Heinrich-Heine-University, \\ Düsseldorf, Germany \\ C. Fonatsch \\ Department of Medical Genetics, Medical University of Vienna, \\ Vienna, Austria

organized together with the MDS Foundation and other international MDS working groups in order to discuss various issues in MDS including minimal diagnostic criteria, classification, algorithms for management and treatment, and therapy [1]. Moreover, the meeting has been a starting point for new groups focusing on specific issues in MDS, such as hematopathology, flow cytometry, or molecular markers. The current meeting in Vienna was organized to provide an update on cooperative studies and to strengthen and support new groups and projects.

\section{Diagnostic criteria and classification}

Standard strategies and algorithms in the diagnosis and classification of MDS were discussed extensively. The group concluded that the diagnosis 'MDS' is based on a three-step algorithm: In a first step, minimal diagnostic criteria, as proposed [1], have to be applied to ensure the diagnosis of MDS. In a second step, it has to be clarified whether the disease is a primary (de novo) MDS (no known mutagenic event) or a secondary MDS following a mutagenic event (often chemotherapy or radio-chemotherapy) [1]. In a third step, WHO criteria [2,3] are applied to define the variant of MDS. The currently available WHO criteria, updated in 2008 [3], represent an extension of FrenchAmerican-British cooperative Study Group criteria [4] that were primarily based on morphologic variables and used as global standard for more than two decades. The WHO classification defines additional variants characterized by cytomorphological and cytogenetic features. Clinically, important variants are the $5 \mathrm{q}-$ syndrome (with good prognosis) and MDS with multilineage dysplasia often associated with a complex karyotype and a grave prognosis. The group discussed the current 2008 update of the WHO classification [3] extensively. Although several issues remain unsatisfactory, the group concluded that this classification, presented in 2008 (Table 2), should be recommended as a global standard.

\section{Histology and immunohistochemistry}

The histology and immunohistochemistry of the bone marrow is an integral and essential diagnostic tool in MDS. In fact, the final correct diagnosis is always based on multiple diagnostic parameters including the bone marrow smear and the bone marrow histology [1]. In the absence of a confirmatory histology, the diagnosis may be missed, incomplete, or incorrect [1]. Typical examples are an underestimated blast cell count (AML in the histology instead of MDS/RAEB in the smear) or overlooked concomitant systemic mastocytosis, SM (SM-MDS) [1, 5]. 
Table 1 Major project lines of the German-Austrian-Swiss MDS group

Validation of the IPSS and of other scoring systems in MDS Standardization and prognostic impact of cytogenetics in MDS Identification of new cytogenetic risk patterns and categories in MDS

Influence of transfusion dependence and iron overload on prognosis in MDS

Impact of gender, age, and comorbidity in MDS

Evaluation of prognostic factors in transplanted MDS patients

Evaluation of prognostic and predictive factors in MDS patients receiving demethylating agents

Evaluation of prognostic and predictive factors in lenalidomidetreated patients

Classification and prognosis of tMDS/tAML

Prognostic impact of eosinophils, basophils, and mast cells

Prognostic impact of bone marrow fibrosis in MDS

Impact of molecular somatic mutations in MDS

Impact of loss of key regulators and tumor suppressor genes

in MDS

Impact of HFE gene mutations on iron overload in MDS

Prognostic value of other germ line mutations in MDS

Prognostic value of serum markers ( $\mathrm{LDH}, \mathrm{sCD} 44$, tryptase,...)

in MDS

Development of dynamic scoring systems in MDS

Evaluation of rare forms of MDS (AT-MDS, MDS-F,

SM-MDS, ...)

Identification of risk factors in CMML

Separate scoring for the two different end points in MDS survival and AML

Evaluation of CD34+/CD38- MDS stem cells and their response to targeted drugs

In addition, the histology provides information regarding cellularity, fibrosis, angiogenesis, focal blast cell accumulations, and megakaryocyte morphology and topology [5-7]. This is especially important in patients with hypoplastic MDS and MDS with fibrosis [5-7]. Immunohistochemistry should be performed in a two-step approach: in a first step, three markers are applied, i.e., CD34 (and KIT), a platelet marker (CD42 or CD61) and tryptase that is expressed in mast cells and less abundantly in (neoplastic) basophils [5]. If the diagnosis is in question, or the histology is pointing at a non-MDS disease, additional markers are applied, the selection of markers depending on clinical, histologic, and molecular findings [5].

\section{Cytogenetics}

Cytogenetic findings in MDS are important with regard to diagnosis, classification, prognostication, and treatment. In patients presenting with only mild signs of dysplasia, the presence of an abnormal karyotype confirms the diagnosis 'MDS' [1]. The presence of an isolated $\operatorname{del}(5 q)$ in 'non- blastic' MDS is of clinical significance [3]. The overwhelming prognostic relevance of cytogenetic findings has recently been confirmed by a collaborative study of the GermanAustrian MDS Study Group [8]. In addition, new insights into the prognostic impact of rare cytogenetic anomalies have accumulated and standards for performing cytogenetic analyses in MDS have been proposed [9, 10]. In the last few years, cytogenetic findings also influenced the choice of treatment. Likewise, patients with isolated $\operatorname{del}(5 q)$ can be treated successfully with lenalidomide [11, 12], patients with aberrations of chromosome 7 may preferentially respond to decitabine [13] or 5-Azacytidine [14], whereas patients with normal (but not high risk) karyotypes may sometimes benefit from intensive (AML-like) induction chemotherapy [15]. Our group cooperates with other international groups with the goal of refining cytogenetics and prognostic scores, one special focus being the relative impact of cytogenetic variables in comparison to blast counts in predicting outcomes in multi-parameter score systems.

\section{Molecular markers and gene variants}

Molecular defects in MDS can be divided into (1) translocation-related fusion gene products, like AML1/ MDS1-EVI-1, found in patients with $\mathrm{t}(3 ; 21)$, (2) somatic gene defects and mutations not reflected by a chromosome defect, like mutations in receptor kinases, RAS, or other signaling molecules, (3) loss of key molecules through deletions (example: loss of RPS14 in 5q patients) or epigenetic silencing, and (4) germ line gene polymorphisms and mutations that may influence the natural course of

Table 2 Classification of MDS according to the WHO proposal (update 2008)

Refractory cytopenias with unilineage dysplasia (RCUD)

Refractory anemia (RA)

Refractory neutropenia (RN)

Refractory thrombocytopenia (RT)

Refractory anemia with ring sideroblasts (RARS, $\geq 15 \%$ ring sideroblasts)

Refractory cytopenia with multilineage dysplasia (RCMD)

Myelodysplastic syndrome - unclassified (MDS-U)

MDS associated with isolated del $(5 q)$

Refractory anemia with excess blasts-1 (RAEB-1, medullary blasts 5-9\%)

Refractory anemia with excess blasts-2 (RAEB-2, medullary blasts $10-19 \%$ )

Childhood myelodysplastic syndrome (separate subchapter, separate authors)

Brunning RD, Orazi A, Germing U, Le Beau MM, Porwit A, Baumann I, Vardiman JW, Hellstrom-Lindberg E (2008) WHO classification of tumours of hematopoietic and lymphoid tissues, Chapter 5, pp 88-107 
disease or disease-related features [16]. One example for the latter are HFE mutations that are otherwise found in patients with hereditary hemochromatosis. The frequency of HFE gene mutations (polymorphisms) in MDS is rather high [17] and may influence iron overload in transfusiondependent patients.

\section{Flow cytometry}

Flow cytometry may be helpful in the diagnosis and prognostication in MDS [1, 18, 19]. The group concluded that evaluation of the percentage of CD34+ myeloid progenitor cells in MDS can be regarded as standard and used in the evaluation of the subtype of MDS, e.g., when the aspirate (smear) is contaminated with blood. CD34+ progenitor cells in MDS may also display aberrant expression of surface molecules confirming the presence of a myeloid neoplasm. In addition, granulocyte and monocyte dysplasia can be recorded by flow cytometry $[1,18,19]$. In fact, aberrant expression of three or more markers on granulocytic and/or monocytic cells can be regarded as a relatively safe indication that the myeloid cells are of monoclonal origin [18-20]. A disadvantage of flow cytometry is that up to now, no standards for evaluations and tests have been developed. Therefore, the group concluded that for the future, it is essential to propose global standards for flow cytometric assessment in MDS.

\section{Prognostication and prognostic score systems}

The prognosis in MDS varies depending on (1) patientrelated factors (age, comorbidity, availability of a stem cell donor) and (2) disease-specific variables, including the variant of disease, cell types affected, cytogenetic features, and genes involved in the malignant process $[1,3,21]$. In addition, the response to specific drugs can in part be predicted by assessment of patient-related and diseaserelated variables. Several useful multi-parameter-based scoring systems have been developed in the past. A widely accepted standard is the International Prognostic Scoring System (IPSS) [22] that includes the medullary blast count, number of cytopenias, and cytogenetic findings. A refinement of the IPSS including the serum LDH has been developed by our group [22]. More recently, several attempts have been made to identify molecular defects that are linked to specific cytogenetic abnormalities or signaling pathways in neoplastic cells in patients with MDS. In addition, the genetic background, including gene polymorphisms and mutations (e.g., deletions), have been discussed as prognostic variables. It has to be pointed out, however, that most data are derived from observational studies on untreated patients. Recently, the WHO-adapted scoring system has been developed, taking into account the degree of dysplasia, chromosomal findings, and transfusion need [23]. This score is even more accurate in identifying patients with a very low risk [23]. Comorbidity scores are currently evaluated in MDS patients. These patient-related parameters not only influence the prognosis but also the choice of treatment [24]. Several projects investigating comorbidity, transfusion effects, and iron overload have recently been started in our MDS study group [24-28]. Recent data suggest that Lenalidomide [11], Decitabine [29, 30], 5-Azazytidine [31], erythropoietin [32], Antithymocyte globulin [33], and others [34] may be beneficial in defined subgroups of MDS patients. We have recently established cooperation projects in our group with the aim to collect data in MDS patients who underwent various therapies in order to better characterize predictive parameters for each patient group.

\section{Future perspectives}

Because of the heterogeneity and complexity of the disease, collaborative work on MDS is essential and should focus on the topics mentioned above, with the ultimate goal of gaining new insights into the pathogenesis of the disease and improving prognostication and therapy [29]. In the future, these studies will also include gene expression profiling, SNP array analysis, and proteomics, as well as flow cytometry and hematopathology. The D-A-CH MDS group will serve as an open forum aiming at intensifying collaborations in these 'subfields' in MDS research.

Acknowledgement Our activities are supported by the German Kompetenznetz Akute und chronische Leukämien of the "Bundesministerium für Bildung und Forschung."

\section{References}

1. Valent P, Horny HP, Bennett JM et al (2007) Definitions and standards in the diagnosis and treatment of the myelodysplastic sydromes: consensus statements and report from a working conference. Leuk Res 31:727-736 doi:10.1016/j.leukres. 2006.11.009

2. Bennett JM (2000) World Health Organization classification of the acute leukemias and myelodysplastic syndrome. Int J Hematol 72:131-133

3. Brunning R, Orazi A, Germing U et al (2008) Myelodysplastic syndromes/neoplasms, overview. In: Swerdlow S (ed) WHO classification of tumours of haematopoietic and lymphoid tissues. IARC, Lyon, pp 88-107

4. Bennett JM, Catovsky D, Daniel MT et al (1982) Proposals for the classification of the myelodysplastic syndromes. Br J Haematol 51:189-199

5. Horny HP, Sotlar K, Valent P (2007) Diagnostic value of histology and immunohistochemistry in myelodysplastic syn- 
dromes. Leuk Res 31:1609-1616 doi:10.1016/j.leukres. 2007.05.010

6. Buesche G, Teoman H, Wilczak W et al (2008) Marrow fibrosis predicts early fatal marrow failure in patients with myelodysplastic syndromes. Leukemia 22:313-322 doi:10.1038/sj. leu. 2405030

7. Schmitt-Graeff A, Mattern D, Köhler H, Hezel J, Lübbert M (2000) Myelodysplastic syndromes (MDS). Aspects of hematopathologic diagnosis. Pathologe 21:1-15 doi:10.1007/ s002920050001

8. Haase D, Germing U, Schanz J et al (2007) New insights into the prognostic impact of the karyotype in MDS and correlation with subtypes: evidence from a core dataset of 2124 patients. Blood 110:4385-4395 doi:10.1182/blood-2007-03-082404

9. Steidl C, Steffens R, Gassmann W et al (2005) Adequate cytogenetic examination in myelodysplastic syndromes: analysis of 529 patients. Leuk Res 29:987 doi:10.1016/j. leukres.2005.01.019

10. Haferlach T, Rieder H, Lillington DM et al (2007) Proposals for standardized protocols for cytogenetic analyses of acute leukemias, chronic lymphocytic leukemia, chronic myeloid leukemia, chronic myeloproliferative disorders, and myelodysplastic syndromes. Genes Chromosomes Cancer 46:494-499 doi:10.1002/ gcc. 20433

11. List A, Kurtin S, Roe DJ et al (2005) Efficacy of lenalidomide in myelodysplastic syndromes. N Engl J Med 352:549-557 doi:10.1056/NEJMoa041668

12. Giagounidis AA, Germing U, Strupp C et al (2005) Prognosis of patients with $\operatorname{del}(5 q)$ MDS and complex karyotype and the possible role of lenalidomide in this patient subgroup. Ann Hematol 84:569-571 doi:10.1007/s00277-005-1054-0

13. Rüter B, Wijermans P, Claus R, Kunzmann R, Lübbert M (2007) Preferential cytogenetic response to continuous intravenous lowdose decitabine (DAC) administration in myelodysplastic syndrome with monosomy 7. Blood 110:1080-1082 doi:10.1182/ blood-2007-03-080630

14. Raj K, John A, Ho A et al (2007) CDKN2B methylation status and isolated chromosome 7 abnormalities predict responses to treatment with 5-azacytidine. Leukemia 21:1937-1944 doi:10.1038/sj.leu.2404796

15. Knipp S, Hildebrand B, Kündgen A et al (2007) Intensive chemotherapy is not recommended for patients aged $>60$ years who have myelodysplastic syndromes or acute myeloid leukemia with high-risk karyotypes. Cancer 110:345-352 doi:10.1002/ cncr.22779

16. Nolte F, Hofmann WK (2008) Myelodysplastic syndromes: molecular pathogenesis and genomic changes. Ann Hematol 87:777-795 doi:10.1007/s00277-008-0502-z

17. Várkonyi J, Demeter J, Tordai A, Andrikovics H (2006) The significance of the hemochromatosis genetic variants in multiple myeloma in comparison to that of myelodysplastic syndrome. Ann Hematol 85:869-871 doi:10.1007/s00277-006-0178-1

18. Loken MR, van de Loosdrecht A, Ogata K, Orfao A, Wells DA (2008) Flow cytometry in myelodysplastic syndromes: report from a working conference. Leuk Res 32:5-17 doi:10.1016/j. leukres.2007.04.020

19. Kern W, Haferlach C, Schnittger S, Haferlach T (2008) Dysplastic features detected by multiparameter flow cytometry in patients with MDS. Onkologie 31(S4):499

20. van de Loosdrecht AA, Westers TM, Westra AH et al (2008) Identification of distinct prognostic subgroups in low- and intermediate-1-risk myelodysplastic syndromes by flow cytometry. Blood 111:1067-1077 doi:10.1182/blood-2007-07-098764

21. Greenberg P, Cox C, LeBeau MM et al (1997) International scoring system for evaluating prognosis in myelodysplastic syndromes. Blood 89:2079-2088

22. Germing U, Hildebrandt B, Pfeilstocker M et al (2005) Refinement of the international prognostic scoring system (IPSS) by including LDH as an additional prognostic variable to improve risk assessment in patients with primary myelodysplastic syndromes (MDS). Leukemia 19:2223-2231 doi:10.1038/sj. leu. 2403963

23. Malcovati L, Germing U, Kuendgen A et al (2007) Timedependent prognostic scoring system for predicting survival and leukemic evolution in myelodysplastic syndromes. J Clin Oncol 25:3503-3510 doi:10.1200/JCO.2006.08.5696

24. Stauder R, Noesslinger T, Pfeilstöcker M et al (2008) Impact of age and comorbidity in myelodysplastic syndromes. J Natl Compr Canc Netw 6:927-934

25. Deschler B, Offermann B, Ihorst G et al (2008) Prospective multidimensional geriatric assessment in 210 patients $>60$ years with MDS/AML. Onkologie 31(S4):V495

26. Pelz D, Nachtkamp K, Kündgen A, Strupp C, Haas R, Germing U (2007) Influence of comorbidity factors on the prognosis of patients with myelodysplastic syndromes (MDS). Leuk Res 31 (S1):15 doi:10.1016/S0145-2126(07)70053-X

27. Böhm A, Sperr WR, Leitner G et al (2008) Comorbidity predicts survival in myelodysplastic syndromes or secondary acute myeloid leukemia after allogeneic stem cell transplantation. Eur J Clin Invest 38:869-873

28. Platzbecker U, Bornhäuser M, Germing U et al (2008) Red blood cell transfusion dependence and outcome after allogeneic peripheral blood stem cell transplantation in patients with de novo myelodysplastic syndrome (MDS). Biol Blood Marrow Transplant 14:1217-1225 doi:10.1016/j.bbmt.2008.08.006

29. Pitako JA, Haas PS, Van den Bosch J et al (2005) Quantification of outpatient management and hospitalization of patients with high-risk myelodysplastic syndrome treated with low-dose decitabine. Ann Hematol 84(S13):25-31 doi:10.1007/s00277-0050007-y

30. Kantarjian H, Issa JP, Rosenfeld CS et al (2006) Decitabine improves patient outcomes in myelodysplastic syndromes: results of a phase III randomized study. Cancer 106:1794-1803 doi:10.1002/cncr.21792

31. Silvermann LR, Demakos EP, Peterson BL et al (2002) Randomized controlled trial of azacitidine in patients with the myelodysplastic syndrome: a study of the Cancer and Leukemia Group B. J Clin Oncol 20:2429-2440 doi:10.1200/JCO.2002. 04.117

32. Park S, Grabar S, Kelaidi C et al (2008) Predictive factors of response and survival in myelodysplastic syndrome treated with erythropoietin and G-CSF: the GFM experience. Blood 111:574582 doi: $10.1182 /$ blood-2007-06-096370

33. Stadler M, Germing U, Kliche KO et al (2004) A prospective, randomised, phase II study of horse antithymocyte globulin vs rabbit antithymocyte globulin as immune-modulating therapy in patients with low-risk myelodysplastic syndromes. Leukemia 18:460-465 doi:10.1038/sj.leu.2403239

34. Nachtkamp K, Kündgen A, Strupp C, Gattermann N, Giagounidis A, Haas R, Germing U et al (2007) Influence of different treatment strategies on the prognosis of patients with MDS. Leuk Res 31(S1):14 doi:10.1016/S0145-2126(07)70052-8 